\title{
ANEKA RAGAM SPIRITUALITAS DALAM KEBUDAYAAN KONTEMPORER
}

\author{
$\mathcal{N}$ gainun $\mathcal{N a i m}$ \\ Sekolah Tinggi Agama Islam Negeri Tulungagung, Jalan Mayor Sudjadi Timur No.46, \\ e-mail: naimmas22@gmail.com
}

Abstract

Spiritualism is an inseparable part of human existence. The reduction of this dimension will effect negatively for human existence. This causes the emergence of new phenomenon, or even culture, in the life of modern society. The phenomenon is the increase of their interest in spiritualism. Even though, spiritualism in this context is not always identical with religion. Even, this phenomenon cannot be separated from capitalism. Therefore, the spiritualism that develops recently has various forms, that is, (1) Spiritualism Secularization, (2) Spiritualism Immanence, (3) Spiritualism Libidinalisation, (4) Schizo-spiritualism, (5) Hybrid-spiritualism, and (6) Techno-spiritualism. Furthermore, there is also another expression of spiritualism, that is, the emergence of new religion or quasi-religion movement. The emergence of this movement is influenced by the effort to release from religious countercultures. Other manifestation of this spiritualism is in the form of fundamentalism movement. In extreme point, this movement can be seen from the emergence of extreme cult, such as those that teach tragic way of death.

Key words: spiritualism, religion, capitalism, fundamentalism, cult. 


\section{Pendahuluan}

Kehidupan modern dengan karakteristik terus berubah secara drastis tanpa bisa dicegah berimplikasi pada tereduksinya dimensi paling fundamental dalam kehidupan manusia, yaitu dimensi spiritualitas. Tereduksinya dimensi spiritualitas berimplikasi pada munculnya beragam persoalan dalam kebudayaan modern, seperti alienasi, anomali sosial, dan berbagai persoalan lainnya. Implikasi lain dari kondisi ini adalah munculnya fenomena budaya baru dalam masyarakat, yaitu kegandrungan terhadap segala hal yang berkaitan dengan spiritualitas. Ketertarikan terhadap dimensi spiritualitas ini ditandai dengan tingginya minat masyarakat, khususnya masyarakat perkotaan, untuk mengikuti berbagai kegiatan yang berhubungan dengan aspek spiritualitas.

Jika menyimak perkembangan kehidupan sosial kemasyarakatan di banyak negara Barat, tampaknya ramalan Naisbitt dan Aburdene menemukan relevansinya. Walaupun tidak sepenuhnya benar, tetapi kecenderungan secara umum membenarkan terhadap ramalan keduanya. Secara umum, ada gairah dan semangat yang meningkat dari masyarakat berhubungan dengan aspek spiritualitas. Inilah yang barangkali disebut Naisbitt dan Aburdene sebagai kebangkitan spiritualitas. Kebangkitan spiritualitas ini ditandai dengan gairah dan semangat yang menggebu dari masyarakat untuk mengikuti aneka ragam kegiatan yang bercorak spiritualitas. Ada yang ikut perkumpulan spiritualitas, ada yang ikut pelatihan, ada yang masuk sekte tertentu, dan ada yang meninggalkan gemerlap kehidupan untuk kemudian memilih tinggal di daerah sepi dan menekuni kegiatan yang dianggap mampu menentramkan jiwa. Begitulah, spiritualitas kini semakin menjadi kebutuhan yang tidak bisa lagi dihindari, bahkan menjadi fenomena baru budaya.

Fenomena ini menarik untuk dicermati secara kritis. Beragam pertanyaan dapat diajukan, seperti; mengapa gejala kebangkitan spiritualitas justru muncul pada masyarakat negara Barat? Bukankah kebutuhan material mereka telah terpenuhi? Pertanyaan demi pertanyaan dapat terus dikembangkan untuk melacak akar persoalannya. Dan jawabannya pun bisa jadi sangat beragam. Namun hampir dapat dipastikan akan adanya 
satu aspek yang bisa disepakati bersama, yaitu hilangnya "sisi dalam" dari kemanusiaan telah membawa kerinduan untuk mencari sesuatu yang hilang. Itulah yang kini dialami oleh manusia modern. Oleh karena itu, berbagai cara pun akan ditempuh; mulai yang normal hingga yang ekstrem. Hal ini disebabkan manusia modern tengah mengalami alienasi.

\section{Prostitusi Spiritualitas}

Kapitalisme telah menjadi ideologi yang mempengaruhi seluruh dimensi kehidupan masyarakat sekarang ini. Gugatan, kritikan, dan perlawanan terhadap kapitalisme yang dinilai sarat dengan eksploitasi dan manipulasi, pada kenyataannya tidak mampu meruntuhkan basis peradaban modern ini (Samekto, 2008: 87). Alih-alih justru kapitalisme kian mengakar kuat dan masuk dalam jaring-jaring kehidupan yang selama ini sebenarnya menjadi musuh utamanya, yaitu agama.

Kuatnya arus kapitalisme, menjadikan segala sisi kehidupan manusia sekarang ini berada dalam kendalinya. Nyaris tidak ada ruang yang tidak tersentuh arus kapitalisme. Salah satu bentuknya adalah imajinasi konsumtif. Dalam imaginasi konsumtif, segala hal berada dalam konstruksi yang berorientasi pada kepuasan. Berbagai ragam paket komersial terus hadir setiap saat, dalam segala formula, lewat beragam media, tanpa mampu dihindari. Nafsu mengkonsumsi terus menerus "dipupuk" dan ditawarkan tanpa pernah ada jeda. Maka, batas konvensional konsumtif akan terus menerus terdesak. Mengkonsumsi bukan lagi karena kebutuhan, tetapi sudah melangkah lebih jauh melampaui hal-hal yang bersifat fisik-material. Mengkonsumsi telah menjadi gaya hidup, status sosial, bahkan hidup itu sendiri. Padahal, kepuasan itu tidak ada batasnya. Tidak pernah ada kepuasan yang final, sehingga ketika kepuasan mengkonsumsi telah mulai memudar atau berkurang, tumbuh kembali keinginan untuk mereguk kepuasan yang baru (Baudrillard, 2006: 6).

Pada titik inilah, fenomena merebaknya aneka ragam formula spiritualitas menemukan penjelasannya. Fenomena maraknya spiritualitas sekarang ini, ternyata tidak hanya merupakan fenomena kebutuhan esensial kemanusiaan 
yang telah direnggut oleh modernitas, tetapi bisa juga merupakan bagian dari the dream world of consumer. Kondisi ini mencuatkan keinginan untuk mengkonsumsi pengalaman-pengalaman pribadi yang baru, termasuk pertemuan-pertemuan bernuansa spiritual yang belum pernah dialami. Jadi, dalam logika ini, pengalaman spiritualitas menempati posisi yang setara dengan pengalaman konsumtif lainnya. Dimensi spiritual disebut oleh Viktor Frankl sebagai noos mengandung semua sifat khas manusia, seperti keinginan untuk memberi makna, berorientasi pada tujuan, kreativitas, imajinasi, intuisi, keimanan, visi tentang mau menjadi apa, kemampuan untuk mencintai di luar kecintaan yang visio-psikologis, kemampuan mendengarkan hati nurani di luar kendali superego, dan selera humor kita. Di dalamnya juga terkandung pembebasan diri kita atau kemampuan untuk melangkah ke luar dan memandang diri kita, dan transendensi diri atau kemampuan untuk menggapai orang yang kita cintai atau mengejar tujuan yang kita yakini. Dalam dunia spirit, kita tidak dipandu; kita adalah pemandu, pengambil keputusan. Namun demikian, dalam kepungan kapitalisme, spiritualitas pun masuk dalam pusaran arus kapitalisme. Spiritualitas tidak lagi menjadi sesuatu yang mendasar yang lahir dari kesadaran akan dimensi yang transendental, tetapi telah menjadi paket-paket yang sarat dengan kepentingan ekonomi. Spiritualitas dalam formula semacam ini telah menjadi komoditas yang sewaktu-waktu dibutuhkan, tapi bisa jadi di lain waktu ditinggalkan.

Fenomena semacam ini sekarang sangat banyak kita temukan. Berkembangnya pengikut latihan-latihan meditasi mistikal yang berorientasi kesalehan instan, larisnya para pedagang spiritual (religious enterpreneurs) yang menjanjikan "jampi-jampi” penenang, digandrunginya para da'i selebritis, atau laris manisnya buku-buku how to spiritual, merupakan contoh konkret dari bentuk konsumerisme pengalaman-pengalaman spiritual. Ketika spiritualitas telah terformula secara materialis, maka akan berimplikasi pada tersingkirnya kesalehan simbolis dan kesalehan aktual. Kesalehan simbolis kemudian memisahkan diri dari kerangka sosial massa dan menjadi kesalehan individual, sementara kesalehan aktual menjadi kesalehan sosial- 
politik. Sikap politik kedua macam kesalehan itu tampak dalam usaha rekayasa iman di tengah masyarakat. Kesalehan individual menekankan pada pietism, sedangkan kesalehan sosial-politik menekankan pada ritualism. Dalam kondisi semacam ini, sangat mungkin spiritualitas akan mengalami "prostitusi" ketika terjadi komersialisasi karena visi religius yang paling esensial telah digadaikan. Padahal, visi ini sesungguhnya mengandaikan kesatuan transenden dari segala hal yang memerlukan pengorbanan ego manusia (Latif \& Ibrahim, 1994: 76).

Kegandrungan mengkonsumsi pengalaman spiritual ini, jika terus berlanjut, akan diikuti oleh menguatnya materialisasi pengalaman spiritual. Ini merupakan sesuatu yang sesungguhnya cukup mencemaskan karena dalam perjalanan umat manusia, belum pernah spiritualisme dalam pergumulannya dengan perubahan secara fundamental terhadap struktur masyarakat mengalami kondisi spiritualisme yang sedemikian ironis.

Implikasi selanjutnya adalah individualisasi pengalaman keberagamaan. Globalisasi dan komodifikasi kebudayaan secara struktural menyuburkan privatisasi agama-agama. Semangat privatisasi ini semakin menemukan lokusnya ketika terjadi perubahan-perubahan penting dalam sruktur-struktur dasar masyarakat, yang dipacu oleh adanya ledakan arus informasi. Suatu ledakan yang membangkitkan pluralisme agama di antara individu-individu, dengan tawaran ekspresi dan visi keagamaannya masing-masing. Pada akhirnya hal ini memberi jalan bagi pilihan-pilihan religiusitas individu-individu, dengan tawaran ekspresi dan visi keagamaannya masing-masing, yang memberi jalan bagi pilihan-pilihan religiusitas individual untuk menerjemahkan dirinya ke dalam tindakan publik.

Temuan Martin Van Bruinessen tentang gerakan tarekat dan aliran mistik lainnya juga menunjukkan terjadinya individualisme religius. Dalam penelitian Bruinessen, saat agama dan perilaku para pemeluknya di berbagai belahan dunia tengah mengalami proses metamorfosa untuk mencari formatnya yang tepat dan unik, agama tidak lagi sebagai alternatif terakhir atau penjamin makna dari nilai-nilai masyarakat pasca industri Barat. Agama hanya berhasil melekat pada bagian pinggir masyarakat. Agama 
akhirnya harus memperbaharui diri lewat praktik-praktik, hubungan-hubungan dan strukturnya. Ia hanya memainkan peran sekunder dalam masyarakat modern (Bruinessen, 1992: 77).

Seringkali spiritualitas diposisikan sebagai salah satu nilai tawar dalam industri kiat praktis. Spiritualitas pun berubah rupa menjadi terapi, dan bukan lagi praktik penempaan dan penyucian jiwa sepanjang hayat. Gairah pencarian akan Tuhan seringkali menjadi tak terbedakan dengan gairah kepenasaran untuk merasakan berbagai sensasi yang seolah-olah spiritual. Sensasi-sensasi tersebut distimulasi melalui berbagai pengondisian psikis. Karenanya, kini pun muncul simulacra mistisisme berupa titik balik, yaitu ketika spiritualitas hanya menjadi semacam terapi untuk mereparasi dan mengembalikan lagi manusia ke pola hidup hedonis dan hasrat keberbutuhannya. Dalam simulacra mistisisme, ada fenomena yang menyerupai "ekstase" namun dialami dalam suatu cara yang tidak bersifat religius. Pengalaman serta kualitas transformasinya pun sangat berbeda bila dibandingkan dengan ekstase mistisisme. Manusia kontemporer cenderung rapuh terhadap penderitaan, karena terbiasa hidup dalam budaya kenikmatan dan keinstanan. Fenomena maraknya buku psikologi popular belakangan ini merepresentasikan meningkatnya kecenderungan orang untuk mencari penyelesaian masalah secara instant.

Jantung spiritualitas bukanlah pada kiat praktis dan instant, atau juga pada kepribadian cangkokan ala buku psikologi popular dan training spiritual. Jantung spiritualitas ada pada permasalahan keunikan tiap manusia, yaitu rahasia misi hidup individu. Rahasia misi hidup tersebut tersimpan jauh di dalam jiwa (bukan psikis) dan ruh. Rahasia misi hidup tersebut hanya bisa diraih dengan penempuhan jalan spiritual yang panjang dan sepenuh hati.

Kecenderungan ini dapat kita lihat dari beberapa aspek. Misalnya ketika agama sering hanya dijadikan sebagai sarana pemuasan pribadi, atau untuk tujuan ketenangan jiwa pemeluknya, sehingga aspek yang disodorkan pun semata-mata menyangkut hubungan pribadi dengan Tuhannya (individuel piety). Dalam tingkat yang ekstrem, bukan suatu kemustahilan jika fungsi profetik keagamaan bisa tercerabut karena agama hanya dijadikan legitimasi untuk "lari" dari alam sosial dan terbang menuju alam psikologis. 
Spiritualisme pun akhirnya hanya dijadikan sebagai sarana perlindungan yang paling memuaskan dan memberikan keamanan psiko-spiritual perseorangan, tetapi tercerabut dari akar masyarakat secara luas. Dalam tingkat yang paling ekstrem, pemuasan psikologis dapat menggiring penganutnya dalam keyakinan mutlak, sebagai pemilik sah semesta kebenaran, dan juga kesempurnaan. Apa pun yang mereka lakukan akan diorientasikan untuk menggapai pemuasan psikologisnya.

Pada titik ini, spiritualisme tidak harus selalu memiliki hubungan dengan Tuhan. Ia acap kali sekedar berfungsi sebagai pelarian psikologis, obsesi dan kebutuhan rohaniah sesaat, serta sekedar untuk memenuhi ambisi mencari ketenangan sementara. Di sinilah terjadi apa yang disebut dengan "komoditi”, "komersialisasi”, "prostitusi”, bahkan "korupsi” spiritual. Spiritual bukan lagi sebagai bentuk penyadaran diri terhadap realitas manusia yang sesungguhnya dan membimbing diri untuk menikmati hidup. Ia dijajakan di pasar-pasar untuk memenuhi ambisi, obsesi, dan selera sesaat konsumen. Maka, spiritualis pun menjadi termaterialisasi.

Oleh karena itu, diperlukan reorientasi dan refleksi ulang terhadap makna dan hakikat spiritualitas dan keberagamaan. Agama bukan hanya iman dan ibadah. Agama adalah Asal yang Ilahi (divine origin). Polanya terletak dalam intelek Ilahiah dan mempunyai tingkat-tingkat eksistensi seperti kosmos sendiri. Kalau agama berhenti berada di bumi, itu tidak berarti bahwa ia berhenti memiliki realitas. Di bumi, lingkaran kehidupan agama dapat berakhir, tetapi agama sendiri sebagai "Ide", dalam pengertian Platonik, akan tetap dalam Intelek.

\section{Bentuk-bentuk Spiritualitas}

Spiritualitas berkembang dan membentuk ekspresi yang sangat beragam. Ia tidak hanya diwakili oleh satu pola ekspresi tertentu, tetapi memiliki beragam pola, dengan titik tekan yang sangat beragam.

Di Indonesia, salah seorang yang memiliki perhatian terhadap persoalan ini adalah Yasraf Amir Piliang. Yasraf memang lebih dikenal sebagai sosok yang memiliki perhatian khusus terhadap permasalahan realitas kebudayaan 
kontemporer. Gaya tulisannya sangat khas dan memiliki analisa yang tajam. Di tangan Yasraf, realitas kebudayaan kontemporer yang carut marut disoroti dengan sangat tajam. Salah satu yang menjadi objek perhatian dan juga keprihatinannya adalah dimensi spiritualitas.

Pemikiran Yasraf tentang spiritualitas menarik untuk dicermati. Dalam pandangan Yasraf, fenomena spiritualitas yang sekarang ini berkembang bukanlah fenomena tunggal. Yasraf menemukan ada beragam manifestasi spiritual yang memformula secara divergen. Pertama, Sekularisasi Spiritualitas. Dalam format ini, terjadi peralihan konsep spiritualitas, yang sebelumnya merupakan domain ketuhanan (Teosofi), beralih menjadi domain akal budi atau cogito (Teknosofi) yang kini menuju ke arah domain hasrat atau kehendak manusia (Libidosofi). Pada era Teosofi, Tuhan sebagai pusat atau sumber, juga sebagai fondasi dari spirit dan spiritualitas. Spirit kepunyaan dan ciptaan Tuhan, dan akan kembali padanya. Spirit didefinisikan sebagai kekuasaan Tuhan. Pada era Teknosofi (pencerahan), akal budi manusia (cogito) sebagai pusat spiritualitas. Nalar manusia memiliki kapasitas untuk mendefinisikan, dan menciptakan yang suci. Pada era Libidosofi, hasrat menjadi pusat, sumber dan fondasi spiritualitas. Hasrat yang mempunyai kekuasaan untuk merumuskan tentang apa itu dunia, apa itu yang spiritual. Hasrat menjadi pusat dunia ketika apa pun perkembangan dunia selalu melandaskan dirinya pada logika hasrat. Kekuasaan dapat diciptakan oleh manusia lewat kemampuan nalar.

Kedua, Imanensi Spiritualitas. Imanensi konsep spiritualitas ini berasal dari Nietzsche. Nietzsche mengatakan bahwa "Tuhan telah mati”, artinya Tuhan tidak lagi mempunyai kekuatan metafisika, sehingga di dalam kehampaan kekuasaan Tuhan itu, manusia berpeluang untuk menjadi Superman, yaitu manusia yang dapat menavigasi dirinya sendiri dalam pencarian tentang apa itu spirit. Imanensi spiritualitas adalah kondisi ketika spiritualitas menjadi efek permukaan, ketika tidak ada lagi kedalaman, dan permukaan merupakan logika dari pancaindra. Ketika konsep spiritualitas ditinggalkan dari fondasi-fondasi transendennya, maka ia dapat berkembang secara produktif pada tingkat permukaan imanen. Spiritualitas adalah apa yang ditangkap dengan pancaindra. 
Spiritualitas adalah sesuatu yang selalu didekonstruksi, atau merupakan aktivitas interpretasi atas interpretasi tanpa henti (Derrida). Spiritualitas bukanlah aktivitas menafsirkan sumber-sumber masa lalunya (logos, Oidos, Tuhan, wahyu) dengan orientasi ke belakang (retrospective). Melainkan sebuah interpretasi ke depan (prospective), sebuah proses penjelajahan tandatanda secara tanpa henti, melalui proses dekonstruksi oposisi biner antara sakral-profan, transenden-imanen, bukan dalam rangka mencari ketetapan makna, tetapi merayakan permainan-permainan dan dunia kemungkinan yang disediakannya.

Ketiga, Libidinalisasi Spiritualitas. Konsep Teosofi selalu mengatakan bahwa segala sesuatu berasal dari Tuhan, yang berwujud spiritual. Artinya realitas merupakan perwujudan hasrat lebih tinggi, yang diarahkan kepada sifat-sifat ketuhanan. Sebaliknya, realitas yang terbentuk sebagai perwujudan hasrat-hasrat rendah (nafs), dianggap sebagai ilusi atau realitas palsu (pseudo reality). Menggunakan analogi platonis, perwujudan hasrat-hasrat rendah itu hanya menghasilkan simulakrum realitas, yaitu realitas yang telah menyimpang dari kehendak Tuhan. Dan, seperti Plato, realitas palsu itu dinilai sangat rendah, dibandingkan realitas spirit lewat mekanisme yang disebut Guattari sebagai mesin hasrat. Ia selalu mencari pelepasan-pelepasan baru, mengikuti pemujaan-pemujaan baru. Apa yang ingin dikendalikan lewat jalan spiritualitas, justru itulah yang ingin dibebaskan oleh mesin hasrat, yang membebaskan hasrat dari pelbagai belenggu, benteng, atau tembok tinggi yang menghalanginya, termasuk belenggu Tuhan (the liberation of desire).

Keempat, Schizo-Spiritualitas. Revolusi hasrat adalah sebuah pergerakan dalam menghancurkan segala bentuk penekanan dan setiap model normalitas yang ada di dalam masyarakat, dengan menggalang sebuah politik hasrat radikal, yang dibebaskan dari segala bentuk sistem kepercayaan. Politik hasrat membiarkan mengalir secara bebas aliran hasrat ke segala arah, dan dengan menghancurkan kode-kode sosial yang menghalanginya. Revolusi hasrat telah membebaskan manusia dari pelbagai aturan keluarga atau sosial, dari pelbagai kepercayaan atau ideologi, dan dari konsep diri dan identitas diri yang tetap dan pasti. 
Lewat kecairan seperti itu, skizofrenia menjadi sebuah wacana produksi hasrat yang sangat produktif dan kreatif, tanpa perlu terikat oleh kedalaman makna dan intensitas bentuk. Deteritorialisasi spiritualitas adalah kehidupan spiritualitas yang tanpa kedudukan, kepastian, atau ketetapan. Hidup mengalir mengikuti energinya sendiri, dan keseketikaan dan kesesaatan yang terus menerus, tanpa ada konsistensi menuju pada sebuah tujuan yang pasti.

Kelima, Hibrid-Spiritualitas. Wacana hibrid-spiritualitas adalah sebuah wacana yang di dalamnya spiritualitas melakukan kawin silang (hibridity) dengan wacana-wacana keduniaan di dalam ruang kontradiksi. Hibrid-spiritualitas adalah kawin silang dari dua kekuatan bertentangan atau lebih menjadi satu kekuatan kontradiktif; ketuhanan-konsumerisme, transenden-imanen, kesucian-kedangkalan. Hibrid-spiritualitas adalah ruang hasrat yang di dalamnya mesin-mesin kecepatan (dromology) melakukan simbiosis dengan mesin kekhusukan. Kecepatan telah mengubah pelbagai bentuk ritual yang kini merupakan spiritualitas kecepatan (dromo-spirituality).

Hibrid-spiritualitas adalah simbiosis antara nafsu rendah dan nafs ketuhanan, simbiosis antara an-nafs al-ammarah dengan an-nafs al-muthma'inah, yang di dalamnya hikmah-hikmah pengendalian hasrat berbenturan dengan logika pelepasan hasrat, yang menghasilkan bentuk baru spiritualitas. Hibridspiritualitas adalah wacana yang di dalamnya jalan spiritualitas merupakan bagian dari gaya hidup, yaitu bercampurnya gaya hidup profan dan spiritualitas yang merupakan bagian dari gaya hidup, yaitu bercampurnya gaya hidup profan dan spiritualitas yang suci: gaya hidup yoga, tenaga dalam, puasa, shalat, zakat, doa, tobat, shalawat, zikir, sufisme.

Keenam, Techno-Spiritualitas. Para visioner teknologi mempunyai obsesi untuk menjadi tuhan lewat kekuatan inteleknya dan kemajuan teknologi informasi yang dikuasainya. Tuhan diciptakan lewat teknologi melalui pelbagai bentuk teknologi pengingkaran.

Ada optimisme bahwa informasi atau elektronika-digital adalah bentuk baru dari spirit, menggantikan spirit sebagai sebuah istilah yang selalu dikaitkan dengan Tuhan. Singkatnya, elektronik-digital adalah bentuk spiritual baru itu. Keabadian adalah metode sibernetik dalam 
mempertahankan kapasitas signal yang unik pada diri seseorang, itulah yang disebut jiwa (Pilliang, 2007: 172-176).

Fenomena kebangkitan spiritualitas yang sekarang merebak di manamana merupakan fenomena yang menarik untuk dicermati. Ada banyak fenomena, penyebab, dialektika, relasi kuasa, dan silang sengkarut yang tidak mudah diurai. Modernitas memang tidak memberi ruang secara memadai. Bagi modernitas, segala hal diukur dari paradigma rasionalitas. Sementara wilayah transendental berada di luar paradigma ini. Padahal, dimensi transendental merupakan bagian tidak terpisah dari eksistensi manusia. Ketika dimensi ini dinafikan, maka manusia meminjam terminologi kalangan perennialis "hidup di pinggir lingkaran eksistensi".

Dalam kerangka ini, manusia melihat segala persoalan dari sudut pandang pinggiran eksistensinya, bukan dari pusat spiritualitas dirinya. Akibatnya, manusia lupa akan dirinya sendiri. Memang, dengan memberikan perhatian pada dunia di luar eksistensi dirinya, manusia memperoleh dunia material yang secara kuantitatif cukup menggiurkan. Namun secara kualitatif dan ditinjau dari keseluruhan tujuan hidupnya yang menyangkut pengertianpengertian mengenai dirinya, ternyata sangat dangkal. Dekadensi, atau "kejatuhan" manusia modern terjadi karena manusia kehilangan pengetahuan langsung mengenai dirinya sendiri dan memiliki ketergantungan terhadap pengetahuan eksternal, yang sebenarnya tidak mempunyai hubungan langsung dengan dirinya.

Dengan tidak diikutkannya dimensi spiritual, kini manusia menuai beragam krisis; mulai krisis yang berkenaan dengan aspek spiritual, pengenalan diri, hingga krisis lingkungan, bahan makanan, maupun kesehatan. Erich Fromm, psikoanalis yang banyak mengkaji fenomena manusia modern, menyatakan bahwa manusia modern sedang mengalami keterasingan (alienasi) dari keseluruhan dimensi kemanusiaannya. Perasaannya telah kosong dan rohaninya rusak. Manusia modern telah mengarahkan pemikirannya pada berhala-berhala yang diciptakan oleh media massa dan pendapat umum, pemerintah, pemimpin politik, sains, dan teknologi. Mereka amat yakin bahwa dirinya mampu mengungkap pikiran-pikirannya. Padahal, dalam 
kenyataannya, apa yang mereka lakukan tidak lebih daripada menerima gagasan-gagasan orang lain saja yang kemudian dianggap sebagai bagian dari dirinya sendiri. Semuanya itu terjadi karena mereka telah memilih hal-hal tersebut sebagai sesembahannya, tuhan-tuhan yang memberikan kebajikan dan pengetahuan. Atas dasar ini, mereka amat bergantung kepada berhala-berhala yang sebenarnya tidak mampu menerima pengabdian dan penyembahan yang mereka lakukan.

Di tengah kegersangan spiritual dan hiruk pikuk hidup dalam peradaban modern, banyak orang yang kemudian berusaha mencari nilainilai yang menyejukkan bagi jiwa mereka. Mereka yang mulai merasakan hilangnya makna-makna mendasar dalam hidup kemudian menekuni berbagai kegiatan keagamaan yang diyakini mampu mengembalikan sesuatu yang telah terenggut dalam belantara modernitas.

Bentuk lain ekspresi spiritualitas adalah munculnya the new religions atau gerakan quasi-religions. Fenomena kemunculan gerakan ini lebih dilatarbelakangi oleh upaya pelepasan diri dari kecemasan, yang oleh sosiolog J. Milton Yinger diistilahkan dengan religious countercultures. Gerakan quasi-religions tumbuh subur berkaitan dengan hippie counter-cultures, yaitu kekecewaan terhadap materialisme dan rasionalisme. Ia lahir sebagai refleksi dari krisis struktural dan normatif secara lebih luas.

Fenomena fundamentalisme keberagamaan yang belakangan marak, sebenarnya memiliki latar belakang penyebab yang hampir sama. Fundamentalisme berpandangan bahwa keimanan harus dipegang teguh secara penuh dan harfiah, tidak mengenal kompromi, keluwesan, interpretasi atau pengurangan (free of compromise, softening, reinterpretation, or diminution). Dalam pandangan fundamentalisme, inti agama adalah doktrin yang harus ditetapkan secara persis dan paripurna. Dalam fundamentalisme, juga terdapat sistem pengkultusan sebagai sumber legitimasi yang mempunyai otoritas pemberian kepuasan dan keselamatan kepada para pengikutnya (Anton, 2003:41).

Memang, pada dasarnya manusia adalah makhluk beragama. Walaupun kebutuhan secara materi mampu terpenuhi, bahkan lebih dari cukup, namun 
manusia tetap butuh terhadap sesuatu yang mampu meneduhkan jiwanya.

\section{Mimpi Eskatologis Menuju Sorga}

Kematian merupakan salah satu misteri Ilahi. Tidak ada seorang manusia pun yang tahu secara pasti kapan maut akan menjemput. Jika Allah menghendaki, kapan saja seseorang bisa meninggal dunia. Bagi semua manusia, kematian sangat mungkin terjadi setiap saat. Ketika takdir kematian datang menjemput, tidak ada seorang manusia pun yang dapat menghindarinya. Walaupun merupakan misteri, tetapi kematian sesungguhnya merupakan sesuatu yang pasti. Bahkan tidak ada kepastian yang melebihi kematian, sebab siapa pun pasti akan mengalaminya. Yang membedakan di antara mereka hanya soal waktu. Tidak peduli orang kaya, orang miskin, penguasa, penjahat, birokrat, atau siapa saja, semuanya akan mati. Kematian benar-benar merupakan sebuah keniscayaan.

Dalam sejarah panjang kehidupan manusia, selalu muncul terus usaha secara serius untuk menggali dan memecahkan misteri kematian. Namun demikian, sampai hari ini pun, semua usaha yang dilakukan manusia belum mampu memecahkan misteri tersebut. Apa yang dilakukan oleh para peneliti untuk memahami misteri kematian dengan meneliti secara akurat sel-sel hidup dan sel-sel mati juga belum berhasil. Sel-sel hidup, sebagaimana ditemukan, akan membangkitkan kegiatan kehidupan, sedangkan sel-sel kematian tidak mampu membangkitkannya; tetapi secara lahiriah, perbedaan itu tidak dapat diketahui sebabnya. Padahal sebenarnya kedua jenis sel itu memiliki materi dan struktur yang sama. Keduanya terdiri atas kalsium, ferum, dan hidrogen. Hanya saja sel-sel hidup mampu- membangkitkan kegiatan yang dahsyat, yang tidak mampu dilakukan oleh sel-sel mati. Selsel hidup itu pun tidak akan mati sampai terhentinya kegiatan kehidupan yang didukungnya. Anehnya, ketika kehidupan terhenti sel-sel itu tidak berkurang strukturnya.

Ketidakmampuan manusia memecahkan misteri kematian ini menunjukkan bahwa kematian berada di luar batas kemampuannya. Apa yang bisa dilakukan manusia dengan ilmu pengetahuan yang dikembangkannya, 
hanyalah sebatas bagaimana berusaha menjauhkan diri dari sebagian sebabsebab kematian. Penemuan mutkahir dalam bidang kedokteran, misalnya, merupakan contoh ikhtiar untuk menjauhkan sebab-sebab kematian. Namun sayangnya, dari berbagai penelitian dan usaha yang dikembangkan, hanya berkisar pada pencegahan penyakit dan pengobatannya, baik yang menyangkut penyakit saraf maupun penyakit jiwa. Akan tetapi, semua kajian itu sama sekali tidak dapat mengusik pengaruh perilaku manusia terhadap panjang umurnya, atau pengaruh dosa terhadap berkurangnya umur. Semua itu kembali kepada perilaku ilmu pengetahuan itu sendiri yang membatasi dirinya hanya pada tabung-tabung penelitian, kajian sebab-akibat yang sifatnya material, dan mengabaikan semua hal yang tidak masuk ke dalam kerangka inderawi dan percobaan yang berdasarkan sebab-akibat tersebut.

Di tengah usaha semacam ini, merupakan fenomena yang menarik manakala menghubungkannya dengan ekspresi keberagamaan dengan kematian. Model dan ekspresi keberagamaan masyarakat sekarang ini kian beragam. Orang tidak bisa lagi mengklaim satu bentuk keberagamaan sebagai yang paling betul, dan ekspresi yang lain sebagai yang salah. Sebab, ekspresi keberagamaan pada hakikatnya adalah usaha untuk menafsirkan agama sebagaimana termuat dalam teks kitab suci. Sebagai ikhtiar menafsirkan, maka tidak boleh ada satu orang atau satu pihak pun yang mengklaim memiliki otoritas tunggal. Persoalannya, sampai sejauh mana batas-batas penghargaan ini? Penghargaan dan toleransi memang bukan berarti membiarkan sama sekali segala bentuk perbedaan. Harus ada batas-batas tertentu untuk membatasi penghargaan terhadap perbedaan ini. Pembatasan ini diperlukan karena kalau tidak ada pembatasan, akan menimbulkan kerusakan atau kerugian.

Dalam konteks ekspresi keberagamaan masyarakat, memang sangat banyak variasi; ada yang liberal, moderat, dan ekstrem. Salah satu fenomena keberagamaan yang sangat menarik perhatian publik pada beberapa tahun lalu adalah Sekte Pondok Nabi di Bandung. Sekte pimpinan Pendeta Mangapin Sibuea ini meyakini bahwa kiamat akan tiba pada tanggal 10 November 2003. Untuk menyongsongnya, ratusan jemaat berkumpul dalam 
gereja sejak tengah malam. Namun sayang, harapan ratusan anggota jemaat Pondok Nabi untuk menyaksikan kiamat sebagaimana yang mereka yakini tidak terwujud, hingga kemudian polisi mengevakuasi mereka. Kehidupan damai di sorga pasca kiamat juga harus tertunda untuk mereka nikmati.

Keyakinan terhadap tanda-tanda hari akhir yang segera terjadi ternyata tidak hanya monopoli kalangan Jemaat Pondok Nabi. Sekte-sekte sejenis ternyata juga terdapat di berbagai belahan dunia, dari beragam agama. Pergantian milenium merupakan salah satu waktu yang diyakini paling banyak sebagai waktu kiamat. Pada pukul 00:00:00 inilah yang menandakan berakhirnya dunia. Walaupun kemudian jelas terbukti, kiamat tidak terjadi. Fenomena semacam Sekte Pondok Nabi seyogyanya menjadi bahan refleksi bersama terhadap keberagamaan kita. Bagaimana pun juga, fenomena tersebut merupakan sebuah tantangan serius terhadap eksistensi agama dalam menjawab tuntutan secara nyata kehidupan umatnya. Sekte ini lebih banyak mengambil perspektif dan gerakan yang menyimpang dari ajaran agama mainstream.

Fenomena Sekte Pondok Nabi, menjadi menarik untuk didiskusikan terutama berkaitan dengan ajaran dan perilaku keberagamaan mereka yang oleh publik dinilai sebagai penuh dengan keanehan. Cara beribadah mereka, relasi sosial anggotanya, dan juga keyakinan eskatologis mereka, merupakan hal yang sama sekali berbeda dengan arus keberagamaan yang dominan. Hal inilah yang menjadikan keberadaan sekte atau aliran sejenis ini menjadi bahan perhatian secara luas. Jika dicermati dinamika dan perkembangan kehidupan keagamaan masyarakat, baik di Indonesia maupun di dunia, dalam beberapa tahun belakangan ini memang diwarnai oleh adanya sekte atau aliran keagamaan yang nyleneh. Sebagai bukti dari kenylenehan ini adalah kesetiaan buta pengikutnya untuk melakukan apa pun, termasuk bunuh diri. Hal ini misalnya dialami oleh pengikut sekte pimpinan Takao di Jepang. Pada bulan Agustus 2001, lima orang pengikutnya tewas dalam sebuah rumah di Osaka akibat melakukan ritual puasa sampai mati. Kematian diyakini para pengikut sekte sebagai jalan pembebasan. Oleh karena itu, bagi anggota sekte, kematian akan mereka hadapi dengan penuh 
ketenangan dan kebanggaan. Dengan menjalani ritual kematian, mereka meyakini akan menemukan apa yang selama ini mereka idam-idamkan.

Di tahun yang sama, 253 orang anggota sekte, termasuk anak-anak, tewas dalam bunuh diri massal di Kampala, Uganda. Jenazah mereka menjadi arang, terserak dalam sebuah gereja yang dijadikan sebagai tempat bunuh diri massal. Anehnya, sekte-sekte jenis ini ternyata ada di masa-mana. Beberapa nama yang sempat dikenal publik dan menimbulkan kontroversi secara luas adalah Branch Davidian pimpinan David Koresh, Heaven's Gate, Kenisah Matahari, Devine Light Mission, Children of God, People's Temple, The Way, Unification Church, Yahweh ben Yahweh, Cristian Identity, The Order, Scientology, dan lain-lain. Gerakan sekte keagamaan yang lebih dikenal sebagai kultus (cult) ini memiliki karakteristik berupa adanya keorganisasian yang sangat kuat, kedisiplinan tinggi dan absolustik. Kultus berpusat pada seorang tokoh kharismatik yang sangat mapan dan menawan di mata para pengikutnya, berdaya retorik tinggi dan menjanjikan keselamatan dan kebahagiaan hidup sejati.

Untuk membangun kepercayaan di mata para pengikutnya, tokoh kharismatis melakukan berbagai usaha secara sistematis. Pakar sekte berbahaya, Ron Enroth dalam buku How to Identify Dangerous Religious Group telah menulis 15 teknik indoktrinasi sebuah sekte berbahaya. Di antaranya orang-orang yang direkrut, diisolasi dari keluarga, teman, dan media sehingga terhindar dari pendapat yang bertentangan. Selain karena kemahiran tokoh kharismatis yang menjadi pemimpin, fenomena sekte juga lekat dengan kebutuhan manusia terhadap kehidupan yang bermakna. Hidup yang bermakna bukanlah sesuatu yang khayali dan artifisial, tetapi merupakan suatu fenomena psikis yang benar-benar nyata dan dirasakan sangat penting dalam kehidupan manusia. Bergabung dalam sebuah sekte, tampaknya salah satunya juga dilatarbelakangi oleh kebutuhan untuk memenuhi kebutuhan hidup yang bermakna.

Sekte yang menawarkan ketenangan dan kebahagiaan hidup kepada para pengikutnya, sebenarnya hanya mampu memberikan jawaban tentatif dari persoalan hidup secara hakiki. Apa yang diberikan sebuah sekte 
dan ajaran eskatologisnya hanyalah sesuatu yang bersifat palliative, yaitu memberi hiburan jangka pendek dan cepat. Jawaban yang diberikan akan menguap seiring perjalanan waktu. Selain itu, jawaban tersebut juga tidak memberikan peluang kepada akal sehat untuk mengkritisinya. Apa yang diberikan oleh sekte lewat sabda pimpinannya, adalah kebenaran tunggal yang tidak bisa diganggu gugat. Walaupun sangat mungkin, ajaran dalam sekte dinilai sebagai bentuk penyimpangan oleh publik.

Penyimpangan perilaku dan gerakan keagamaan seperti yang dilakukan oleh sekte yang mengajarkan hal-hal yang menyimpang, seperti ajaran bunuh diri, dapat dianalisis dengan pendekatan psikologi sugesti. Istilah psikologi sugesti digunakan oleh para ahli psikologi untuk proses yang diamati dalam berbagai eksperimen dengan hipnotisme. Dalam analisisnya, Robert H Thouless mencontohkan bagaimana tukang hipnotis meyakinkan seseorang melalui persepsi yang diciptakannya. Dalam kasus sugesti yang berhasil, gagasan yang disugestikan oleh tukang hipnotis kepada orang yang bersangkutan sudah berubah menjadi persepsi, perbuatan, atau keyakinan. Dengan demikian, sugesti dapat pula dijadikan sebagai alat untuk mengkomunikasikan gagasan-gagasan keagamaan. Setidaknya terdapat lima karakteristik sekte atau kelompok yang dapat dikategorikan sebagai sekte yang membangun mimpi eskatologis menuju sorga lewat ajakan bunuh diri, meyakini datangnya kiamat, dan sejenisnya. Pertama, pelakunya menokohkan diri selaku orang suci dan umumnya tidak memiliki latar belakang yang jelas (asing). Kedua, mendakwahkan diri memiliki kemampuan luar biasa dalam masalah yang berhubungan dengan hal-hal gaib. Ketiga, menggunakan ajaran agama sebagai alat untuk menarik kepercayaan masyarakat. Keempat, kebenaran ajarannya tidak dapat dibuktikan secara rasional. Kelima, memiliki tujuan tertentu yang cenderung merugikan masyarakat (Jalaluddin, 2002: 89-92).

Fenomena bunuh diri dari kelompok sekte tertentu menarik dicermati dengan pendekatan teodisi yang dipopulerkan Peter L. Berger dalam Sacred Canopy. Istilah 'teodisi' berasal dari bahasa Yunani, yang secara harfiah berarti prinsip keadilan Tuhan. Dari sudut pandang filsafat agama, prinsip ini kemudian dipahami sebagai sebuah formula rasionalitas meta-fisis yang 
muncul dari keyakinan iman ketika seseorang menghadapi peristiwa-peristiwa tragis, agar yang bersangkutan bisa menerimanya dengan tabah, rasional tanpa harus menyalahkan Tuhan.

Menurut alur logika ini, Tuhan selalu benar, adil, dan manusia selalu dalam pihak yang salah, dan oleh karenanya kalau tertimpa tragedi harus dipahami sebagai hukuman Tuhan atas dosa-dosanya. Karena hidup manusia selalu dibayangi oleh peristiwa tragis, dan puncaknya adalah sebuah kematian yang tak terkalahkan, maka setiap pemeluk agama meyakini konsep teodisi sebagai sebuah pembelaan atas keadilan Tuhan dan agar bisa menjalani hidup dengan tabah dan tetap memiliki optimisme eskatologis. Keyakinan akan keadilan Tuhan itu pada urutannya melahirkan konsep langit suci yang senantiasa memayungi manusia, dan menyediakan jawaban atas semua peristiwa tragis yang sewaktu-waktu bisa terjadi. Tanpa payung langit suci maka kehidupan menjadi absurd, tak bermakna dan kegelisahan akan selalu menyertainya. Kemajuan Iptek membuat bangunan langit suci bagi sebagian masyarakat Barat semakin kabur dan koyak. Keyakinan dan praktik keagamaan tradisional semakin menipis. Yang subur adalah pseudoreligion atau cultic religions yang termasuk kategori gerakan New Age. Ketika sebuah komunitas agama masih hidup dalam satu kelompok eksklusif, terpisah total dari pemeluk agama lain, mereka mudah untuk meyakini hanya satu langit suci.

Secara sosiologis-antropologis, konsep langit suci berperan mengikat warga masyarakat karena ia disakralkan, dibela serta diwariskan secara turun temurun sehingga dunia makna tidak goyah. Siapa yang menggugat dalil-dalil langit suci, ia akan dikucilkan masyarakat. Namun, keutuhan dan keteduhan bangunan keyakinan itu goyah ketika batas-batas geografis dan kultural sebuah agama melebar, dan kemudian bertemu dengan tradisi agama lain sehingga hamparan langitnya menjadi samar dan kelam. Ketika konsep keselamatan dan jawaban ultima dari sebuah tradisi digugat dan dikompetisikan, maka seseorang mudah menjadi gelisah dan jawaban iman yang dipegang erat tidak lagi memberikan jawaban mujarab (Sukidi, 2001: 70).

el-Harakah, Vol. 11, No.1, Tahun 2009 
Dalam masyarakat Barat, di samping karena bertemu dengan tradisi agama Timur, sumber kegelisahan yang mengguncang tatanan langit suci, terutama datang dari kemajuan ilmu pengetahuan dan filsafat positivisme. Keduanya telah mencabik-cabik konsep tradisional teodisi serta membongkar struktur psikologis sacred canopy. Terkoyaknya langit suci semakin terasakan dengan meletusnya Perang Dunia II dan ketika lembaga serta doktrin agama tidak berdaya menghentikan krisis-krisis kemanusiaan.

Terlepas dari berbagai kritik terhadap keberadaan sekte dan aliran nyleneh yang belakangan semakin marak, fenomena ini sesungguhnya menghadirkan pembelajaran yang sangat berarti bagi kehidupan beragama secara umum. Fenomena sekte, ajaran atau keyakinan eskatologis yang riil, seperti keyakinan akan datangnya hari kiamat, seharusnya menjadi wahana otokritik bagi kehidupan keberagamaan secara luas. Kondisi ini menunjukkan bahwa pencarian hidup yang bermakna semakin lekat dalam kehidupan masyarakat. Dalam konteks semacam inilah, dibutuhkan metodologi implementasi ajaran agama yang tepat dan aplikatif. Ketika peran semacam ini gagal dilaksanakan, terutama oleh agama formal, maka peluang sekte yang menjanjikan mimpi eskatologis menuju sorga akan semakin terbuka lebar. Sangat mungkin sekte sejenis Pondok Nabi akan bermunculan lagi, tidak memandang asal ajaran agama formalnya.

Menurut Alvin Toffler, kultus (cult) adalah bentuk gerakan spiritual (dan keagamaan) dengan sistem pengorganisasian yang ketat, penuh disiplin, absolutistik, dan, dengan sendirinya, kurang toleran kepada kelompok lain. Kultus biasanya berpusat pada ketokohan seorang pribadi yang menarik, berdaya pikat retorik yang memukau, dan dengan sederhana, namun penuh keteguhan, menjanjikan keselamatan dan kebahagiaan. Bagi Toffler, merajalelanya kultus adalah gejala sosial yang membingungkan, yang hanya dapat diterangkan jika kita melihat gejala-gejala negatif masyarakat industri, yaitu kesepian, hilangnya struktur masyarakat yang kukuh, dan ambruknya makna yang berlaku (Toffler, 1990: 374). Dalam kata lain, masyarakat industri telah mengakibatkan alienasi atau keterasingan pada diri pribadi para anggotanya. Fromm menyatakan;

"Alienasi yang kita temukan dalam masyarakat modern adalah hampir total; ia meliputi hubungan manusia dengan pekerjaannya, ke benda- 
benda yang ia konsumsi, ke negara, ke sesamanya, dan ke dirinya sendiri. Manusia telah menciptakan suatu dunia dari barang-barang buatan manusia yang tidak pernah ada sebelumnya. Ia telah membangun permesinan sosial yang ruwet untuk mengatur permesinan teknis yang ia bangun. Namun seluruh kreasinya itu tegak di atas dan mengatasi dirinya sendiri. Memang ia merasa dirinya sebagai pencipta dan pusat, tapi juga sebagai budak sekaligus berhala Golem yang ia buat dengan tangannya sendiri. Semakin kuat dan besar kekuatan yang ia lepaskan, semakin ia merasa dirinya tak berdaya sebagai manusia. Ia menghadapi dirinya sendiri dengan kekuatan dirinya yang dikandung dalam bendabenda yang ia ciptakan, yang terasing dari dirinya sendiri. Ia dikuasai oleh kreasinya sendiri, dan telah kehilangan kekuasaan terhadap dirinya sendiri. Ia telah membuat sebuah patung anak sapi emas, dan berkata, "inilah dewamu yang membawa kamu keluar dari Mesir" (Fromm, 1972: 124-125).

Alienasi inilah yang menyebabkan orang tertarik kepada kultus, sebab alienasi menimbulkan rasa kesepian yang mencekam, yang merindukan perkawanan akrab dan hangat, yang mendambakan suatu penjelasan tentang apa dan ke mana hidup ini. Toffler menjelaskan:

"Untuk orang-orang yang kesepian, kultus-kultus menawarkan, pada permulaannya, persahabatan yang merata. Kata seorang petugas Unification Church: "Kalau ada orang kesepian, kita bicara kepada mereka. Banyak orang kesepian di sekitar kita". Pendatang baru itu dikelilingi oleh orang-orang yang menawarkan persahabatan dan isyarat dukungan kuat. Banyak kultus yang menghendaki kehidupan komunal. Kehangatan dan perhatian yang tiba-tiba ini sedemikian kuatnya memberi rasa kebaikan sehingga anggota-anggota kultus sering bersedia untuk memutuskan hubungan dari keluarga dan teman-teman lama mereka, untuk mendermakan penghasilannya kepaa kultus, (kadang-kadang) menerima narkotika dan bahkan seks sebagai imbalan.

Tetapi kultus menawarkan lebih banyak daripada sekedar perkumpulan. Ia juga menawarkan struktur yang banyak dibutuhkan. Kultus-kultus menyodorkan ketentuan-ketentuan yang ketat pada tingkah laku. Mereka menuntut dan menciptakan disiplin yang amat kuat, sebagian nampaknya bertindak begitu jauh sehingga memaksakan disiplin itu melalui penyiksaan, kerja paksa, dan bentuk-bentuk kurungan dan penjara yang mereka buat sendiri” (Toffler, 1990: 375). 
Dalam kenyataannya, ketenangan batin yang diberikan kultus hanya bersifat sementara. Efek sebuah kultus bersifat palliative, yakni memberi hiburan cepat dan jangka pendek, dan ada unsur kepalsuan didalamnya.

\section{Simpulan}

Fenomena kebangkitan spiritualitas memang telah menjadi wajah baru dalam masyarakat modern. Apa yang penulis paparkan dalam tulisan ini memang lebih memfokuskan bahasan pada aneka ragam fenomena spiritualitas yang secara umum kurang memiliki apresiasi positif terhadap agama. Fokus ini dimaksudkan untuk melihat bahwa kebangkitan spiritualitas tidak selalu berkonotasi positif, sebab sangat mungkin justru membawa persoalan yang serius dalam kehidupan sosial kemasyarakatan. Justru dengan melihat adanya beraneka persoalan semacam ini, dapat menjadi bahan refleksi, renungan, sekaligus membangun kerangka pandang yang lebih positif untuk membangun metodologi yang tepat dalam menghadapinya. Selain itu, fenomena ini juga menjadi tantangan yang serius bagi agama, juga para pemukanya.

Namun demikian bukan berarti penulis menggeneralisasi bahwa setiap fenomena kebangkitan spiritualitas berarti terpisah dari agama, dan berkonotasi negatif. Ada cukup banyak perkembangan positif dan konstruktif dari fenomena ini. Bahkan jauh lebih banyak dan menggembirakan. Namun, fenomena semacam ini memang di luar konteks bahasan tulisan ini. Wallahu a'lam.

\section{Daftar Pustaka}

Baudrillard, Jean P. 2006. Masyarakat Konsumsi. Terjemahan oleh Wahyunto. Cetakan ke 2. Yogyakarta: Kreasi Wacana.

Fromm, Erich. 1971. The Sane Society. New York: Holt, Reinehart and Winston. Jalaluddin. 2002. Psikologi Agama. Jakarta: Rajawali Press.

Naisbitt, John etc. 1990. Megatrend 2000. New York: William Morrow \& Company. 
Richard T, Anton. 2003. Memahami Fundamentalisme. Terjemahan oleh Muhammad Shodiq. Surabaya: Pustaka Eureka.

Samekto, FX Adji. 2008. Kapitalisme, Modernisasi, dan Kerusakan Lingkungan. Yogyakarta: Genta Press.

Sukidi. 2001. New Age, Wisata Spiritual Lintas Agama. Jakarta: Gramedia. Toffler, Alvin,. 1990. The Third Wave. New York: Bantam Books.

Van Bruinessen, Martin. 1992. Gerakan Sempalan di Kalangan Umat Islam Indonesia: Latar Belakang Sosial Budaya. Jurnal Ulumul Quran. Vol. III. No. 1.

Wora, Emmanuel. 2006. Perenialisme, Kritik atas Modernitas dan Postmodernisme. Yogyakarta: Kanisius.

Yasraf, Amir Pilliang. 2007. Membaca Spirit Dunia; Fenomenologi, Semiotika Realitas, Spiritualitas. Dalam Alfatri Adlin (Ed.), Spiritualitas dan Realitas Kebudayaan Kontemporer. Yogyakarta-Bandung: Jalasutra.

Yudi, Latif dkk. 1994. "Kekerasan” Spiritual dalam Masyarakat Pasca-Modern. Jurnal Ulumul Quran. Vol. V. No. 3. 